\title{
MOTIVASI PETANI MUDA DALAM PENERAPAN TEKNIK BUDIDAYA PADI SAWAH SECARA ORGANIK DENGAN METODE SYSTEM OF RICE INTENSIFICATION (STUDI KASUS DI KELOMPOK TANI MEKAR SARI IV, DESA CIAPUS, KEC. BANJARAN, KAB. BANDUNG)
}

\author{
Akmal Fathurrahman dan Lucyana Trimo \\ Departemen Sosial Ekonomi Program Studi Agribisnis Fakultas Pertanian \\ Universitas Padjadjaran \\ E-mail: akmalf02@gmail.com
}

\begin{abstract}
ABSTRAK
Penelitian ini bertujuan untuk mengidentifikasi tingkat motivasi petani muda dalam menerapkan teknik budidaya padi sawah organik dengan metode SRI, serta mengetahui faktor-faktor yang berhubungan dengan motivasi petani muda tersebut dalam penerapan teknik budidaya padi sawah organik dengan metode SRI. Penelitian ini dilakukan di Kelompok Tani Mekar Sari IV, Desa Ciapus, Kecamatan Banjaran, Kabupaten Bandung, Jawa Barat. Teknik pengambilan data dilakukan secara sensus terhadap petani muda anggota kelompok tani tersebut yang menerapkan teknik budidaya padi sawah organik dengan metode SRI, yang berjumlah 30 orang. Desain penelitian ini adalah kualitatif, dengan ditunjang data kuantitatif untuk menyatakan hubungan antara faktor-faktor internal dan eksternal petani muda dengan motivasinya untuk menerapkan teknik budidaya padi sawah tersebut. Teknik penelitian yang digunakan adalah deskriptif dengan pendekatan korelasional, serta dilakukan uji korelasi Tau B-Kendall untuk mengolah data kuantitatif yang diperoleh. Hasil penelitian menunjukkan bahwa tingkat motivasi petani muda untuk menerapkan teknik budidaya padi sawah tersebut tergolong kategori tinggi. Faktor internal petani muda yang berhubungan nyata terhadap motivasinya dalam menerapkan teknik budidaya padi sawah tersebut adalah umur petani, pendidikan non formal dan akses informasi, sedangkan faktor eksternalnya adalah ketersediaan sarana dan prasarana produksi, serta karakteristik inovasi teknik budidaya padi sawah tersebut.
\end{abstract}

Kata kunci: motivasi, petani muda, padi organik, metode SRI

\begin{abstract}
This research aimed to identify level of young farmer's motivation and discover factors related to the motivation of young farmers at implementing organic wet paddy cultivation technique with SRI method. This research is held in Kelompok Tani Mekar Sari IV, Desa Ciapus, Kecamatan Banjaran, Kabupaten Bandung, Jawa Barat. Data in this research obtained with sensus technique to 30 members in young age of Kelompok Tani Mekar Sari IV. Desain of this research is qualitative, supported by quantitative data to state relation between internal and external factors of young farmers in their motivation to implement organic wet paddy cultivation technique used. This research applies descriptive technique with correlational approach. Correlaton Tau B-Kendall test is used to process quantitative data obtained. The result of this research shows level of young farmers motivation to implement organic wet paddy cultivation technique with SRI method is classified in high category. The internal factors of young farmers that significantly correlate to their motivation in implementation of organic wet paddy cultivation technique with SRI method are farmer's age, non formal education, and information access. The external factors of young farmers that significantly correlate to their motivation in implementation of organic wet paddy cultivation technique with SRI method are the availability of farming facilities, and the characteristics of innovation.
\end{abstract}

Keywords: motivation, young farmers, organic paddy, SRI method 


\section{PENDAHULUAN}

Di Indonesia, padi adalah merupakan tanaman serealia yang termasuk komoditas pertanian yang menghasilkan kebutuhan pangan pokok bagi masyarakat, yaitu beras. Beras mempunyai peran strategis dalam memantapkan ketahanan pangan, ekonomi, dan stabilitas politik nasional (Sumarno, 2007). Oleh karenanya, komoditas padi perlu diberikan perhatian dan penanganan pengembangan yang lebih banyak supaya ketahanan pangan Indonesia dapat terjaga.

Tujuan mencapai ketahanan pangan bagi negara, seharusnya dilakukan dengan kaidahkaidah pertanian berkelanjutan yang mempertimbangan beberapa aspek, yaitu: aspek kesadaran lingkungan; bernilai ekonomis; dan berwatak sosial atau kemasyarakatan. Penerapan konsep pertanian berkelanjutan bukan semata-mata tanpa alasan. Lahan-lahan sawah khususnya di Pulau Jawa yang memiliki peran sebagai sentra produksi padi menunjukkan indikasi kuat adanya penurunan produktivitas (Salikin, 2003).

Pertanian organik muncul sebagai solusi bagi keadaan lingkungan pertanian yang kini semakin terdegradasi akibat penggunaan bahan sintetis. Selain itu, pertanian organik juga dapat menjaga keamanan pangan bagi produk yang dihasilkannya. Salah satu metode dari pelaksanaan pertanian organik bagi komoditas padi, adalah dengan metode System of Rice Intensification (SRI). Penerapan metode SRI ini seringkali dijadikan salah satu metode pelaksanaan pada pertanian padi dengan sistem organik yang mampu meningkatkan produktivitas tanaman padi (Makarim dan Ikhwani, 2012).

Selain dalam aspek pencapaian ketahanan pangan, hasil dari penerapan sistem pertanian organik juga dapat dilakukan dalam rangka peningkatan pendapatan petani. Konsumsi makanan organik saat ini seakan tengah menjadi tren dalam beberapa tahun terakhir. Berdasarkan data dari IFOAM (2015), telah terjadi peningkatan penjualan ritel pangan organik dunia sebesar lima kali lipat dari tahun 1999 sampai tahun 2014, yaitu dari USD 15,2 milyar hingga USD 80 milyar.

Kualitas sumber daya petani yang baik tentu akan menghasilkan tingkat produktivitas petani yang tinggi. Kualitas sumber daya dapat petani dipengaruhi oleh berbagai faktor, salah satunya adalah umur petani. Dari segi umur, rata-rata umur petani di Indonesia adalah di atas 40 tahun (Arsyad, 2008). Berdasarkan Undang-Undang Nomor 13 Tahun 1998 tentang Kesejahteraan Lanjut Usia, umur 60 tahun adalah termasuk kategori lanjut usia/tua dengan dimulai umur 45 tahun yang termasuk kategori pra lanjut usia. Rendahnya minat masyarakat berumur muda untuk bekerja di bidang pertanian, salah satunya disebabkan karena masyarakat berumur muda tersebut ingin memiliki pekerjaan dengan pendapatan yang pasti sesuai dengan Upah Minimum Regional (UMR) yang berlaku.

Disamping faktor lain yang turut mempengaruhi selain umur, petani yang tergolong umur tua biasanya memiliki sifat cenderung sangat konservatif dalam menyikapi perubahan atau inovasi teknologi.

Motivasi kerja merupakan salah satu unsur penting dalam peningkatan produktivitas petani. Motivasi diartikan sebagai faktor-faktor yang mengarahkan dan mendorong perilaku atau keinginan seseorang untuk melakukan kegiatan yang dinyatakan dalam bentuk usaha yang keras atau lemah (Hariandja, 2002).

Fenomena yang menarik terdapat di Kelompok Tani Mekar Sari IV, Kecamatan Banjaran, Kabupaten Bandung, Jawa Barat. Sebanyak $81,75 \%$ anggotanya adalah tergolong ke dalam petani berumur muda dan membudidayakan padi secara organik dengan metode SRI. Berangkat dari fenomena tersebut, diperlukan penelitian untuk mengetahui tingkat motivasi dan faktor yang menentukan motivasi para petani muda yang termasuk dalam anggota Kelompok Tani Mekar Sari IV, sehingga mereka tertarik untuk menerapkan teknik budidaya padi secara organik dengan metode SRI.

\section{METODE PENELITIAN}

Desain penelitian yang digunakan adalah desain kualitatif, dengan ditunjang data kuantitatif untuk menyatakan hubungan antara faktor-faktor internal dan eksternal petani muda dengan motivasinya untuk menerapkan teknik budidaya padi sawah secara organik dengan metode SRI. Teknik penelitian yang digunakan adalah penelitian deskriptif dengan pendekatan korelasional, serta dilakukan uji korelasional Tau B-Kendall untuk mengolah data kuantitatif yang diperoleh. Penelitian dilakukan di Kelompok Tani Mekar Sari IV, Desa Ciapus, Kecamatan Banjaran, Kabupaten 
Bandung, Jawa Barat Penelitian dilakukan dari tanggal 14 Februari 2017 sampai 13 Maret 2017. Teknik pengambilan data dilakukan secara sensus terhadap petani muda anggota Kelompok Tani Mekar Sari IV yang menerapkan teknik budidaya padi sawah secara organik dengan metode SRI. Diperlukan juga data sekunder yang berasal dari kantor desa lokasi penelitian, UPT PPP Kecamatan Banjaran, serta dari studi literatur.

\section{HASIL DAN PEMBAHASAN}

\section{Karakteristik Petani Muda}

\section{- Faktor Internal Petani Muda}

Faktor internal petani muda yang diamati dalam penelitian ini adalah umur, pendidikan formal, pendidikan non formal, pengalaman berusahatani, jumlah tanggungan keluarga, luas lahan garapan, dan akses informasi. Informasi mengenai faktor internal petani muda anggota Kelompok Tani Mekar Sari IV yang menerapkan teknik budidaya padi sawah secara organik dengan metode SRI, disajikan dalam Tabel 1.

Tabel 1. Faktor Internal Petani Muda

\begin{tabular}{|c|c|c|c|}
\hline Faktor Internal & Kategori & $\begin{array}{l}\text { Jumlah } \\
\text { (orang) }\end{array}$ & $\begin{array}{c}\text { Persentase } \\
(\%)\end{array}$ \\
\hline \multirow[t]{3}{*}{ Umur } & Dewasa awal (18-31 tahun) & 0 & 0,0 \\
\hline & Dewasa akhir (32-45 tahun) & 16 & 53,3 \\
\hline & Pra Lansia (46-59 tahun) & 14 & 46,7 \\
\hline \multirow[t]{3}{*}{ Pendidikan formal } & Rendah ( $<10$ tahun) & 22 & 73,3 \\
\hline & Sedang (10-12 tahun) & 6 & 20,0 \\
\hline & Tinggi ( $>12$ tahun) & 2 & 6,7 \\
\hline \multirow[t]{3}{*}{ Pendidikan non formal } & Sedikit ( $<1$ kali) & 13 & 43,3 \\
\hline & Sedang (1-2 kali) & 16 & 53,3 \\
\hline & Banyak ( $>2$ kali) & 1 & 3,3 \\
\hline \multirow[t]{3}{*}{ Pengalaman berusahatani } & Rendah ( $<15$ tahun) & 10 & 33,3 \\
\hline & Sedang (15-27 tahun) & 12 & 40,0 \\
\hline & Tinggi ( $>27$ tahun) & 8 & 26,7 \\
\hline Jumlah tanggungan & Rendah ( $<3$ orang) & 15 & 50,0 \\
\hline \multirow[t]{2}{*}{ keluarga } & Sedang ( 34 orang) & 12 & 40,0 \\
\hline & Tinggi ( $>4$ orang) & 3 & 10,0 \\
\hline \multirow[t]{3}{*}{ Luas lahan garapan } & Sempit ( $<0,5$ hektar) & 27 & 90,0 \\
\hline & Sedang (0,5-2 hektar) & 3 & 10,0 \\
\hline & Luas $(>2$ hektar) & 0 & 0,0 \\
\hline \multirow[t]{3}{*}{ Akses informasi } & Rendah ( $<6$ kali) & 22 & 73,3 \\
\hline & Sedang (6-10 kali) & 1 & 3,3 \\
\hline & Tinggi ( $>10 \mathrm{kali}$ ) & 7 & 23,3 \\
\hline
\end{tabular}

Keterangan: $\mathrm{N}=30$ orang

Petani muda dengan umur paling muda, yang menerapkan teknik budidaya padi sawah secara organik dengan metode SRI di Kelompok Tani Mekar Sari IV adalah 32 tahun, sedangkan yang paling tinggi adalah 59 tahun. Rata-rata umur petani muda di Kelompok Tani Mekar Sari IV adalah 45 tahun.

Tingkat pendidikan formal petani muda yang menerapkan teknik budidaya padi sawah secara organik dengan metode SRI di Kelompok Tani Mekar Sari IV pada umumnya termasuk kategori rendah ( $<10$ tahun), atau setingkat dengan SD dan SMP. Rata-rata pendidikan non formal yang pernah diikuti oleh petani muda anggota Kelompok Tani Mekar Sari IV adalah 1 kali. Pada umumnya, petani muda anggota kelompok tani ini sudah pernah mengikuti 1 kali pelatihan mengenai padi organik yang diadakan oleh PT PLN melalui program CSR-nya yang diadakan dari tahun 2010 sampai tahun 2014.

Rata-rata pengalaman berusahatani padi sawah petani muda anggota Kelompok Tani Mekar Sari IV adalah selama 19,3 tahun, dengan pengalaman berusahatani yang paling sebentar adalah 2 tahun dan paling lama adalah 40 tahun. Rata-rata jumlah tanggungan keluarga yang dimiliki oleh petani muda anggota Kelompok Tani Mekar Sari IV yang menerapkan teknik budidaya padi sawah secara organik dengan metode SRI adalah 2 orang.

Rata-rata luas lahan yang digarap oleh petani muda adalah $0,23 \mathrm{Ha}$, dengan luas lahan garapan tersempit adalah $0,07 \mathrm{Ha}$ dan terluas adalah $0,70 \mathrm{Ha}$. Pada umumnya luas lahan yang digarap oleh petani muda anggota Kelompok Tani Mekar Sari IV adalah tergolong kategori sempit.

Rata-rata petani muda anggota Kelompok Tani Mekar Sari IV yang menerapkan teknik budidaya padi sawah secara organik dengan metode SRI dalam mengakses informasi mengenai padi organik adalah 4-5 kali. Sebanyak 73,3\% petani muda masih tergolong ke dalam kategori rendah dalam hal akses informasinya.

\section{- Faktor Eksternal Petani Muda}

Faktor eksternal petani muda yang diamati dalam penelitian ini adalah ketersediaan modal dana, ketersediaan sarana dan prasarana produksi, intensitas penyuluhan, karakteristik inovasi, dan peluang pasar. Informasi mengenai faktor eksternal petani muda anggota Kelompok Tani Mekar Sari IV yang menerapkan teknik budidaya padi sawah secara organik dengan metode SRI, dapat dilihat dalam Tabel 2. 
Tabel 2. Faktor Eksternal Petani Muda

\begin{tabular}{llrr}
\hline \multicolumn{1}{c}{ Faktor Eksternal } & \multicolumn{1}{c}{ Kategori } & $\begin{array}{r}\text { Jumlah } \\
\text { (orang) }\end{array}$ & $\begin{array}{c}\text { Persentase } \\
\text { (\%) }\end{array}$ \\
\hline Ketersediaan modal dana & Rendah ( $<$ Rp 1.200.000) & 23 & 76,7 \\
& Sedang (Rp 1.200.000-Rp & 5 & 16,7 \\
& 2.000.000) & 2 & 6,7 \\
& Tinggi ( $>$ Rp 2.000.000) & & \\
\hline Ketersediaan sarana dan & Rendah (skor <36) & 0 & 0 \\
prasarana produksi & Sedang (skor 36-53) & 20 & 66,7 \\
& Tinggi (skor >53) & 10 & 33,3 \\
\hline Intensitas penyuluhan & Rendah ( $<9$ kali) & 29 & 96,7 \\
& Sedang (9-16 kali) & 1 & 3,3 \\
& Tinggi (>16 kali) & 0 & 0 \\
\hline Karakteristik inovasi & Rendah (skor <20) & 0 & 0 \\
& Sedang (skor 20-29) & 17 & 56,7 \\
& Tinggi (skor >29) & 13 & 43,4 \\
\hline Peluang pasar & Rendah (skor <7) & 8 & 26,7 \\
& Sedang (skor 7-10) & 18 & 60 \\
& Tinggi (skor >10) & 4 & 13,3 \\
\hline
\end{tabular}

Keterangan: $\mathrm{N}=30$ orang

Rata-rata jumlah modal dana yang digunakan oleh petani muda anggota Kelompok Tani Mekar Sari IV dalam menerapkan teknik budidaya padi sawah secara organik dengan metode SRI adalah Rp 998.000 per musimnya.

Ketersediaan sarana dan prasarana produksi diukur dari penilaian petani muda terhadap ketersediaan dan keterjangkauannya jumlah serta jenis peralatan, pupuk dan MOL, pestisida nabati, bibit unggul, dan alat transportasi yang digunakan serta kondisi prasarana dalam kegiatan budidaya padi secara organik dengan metode SRI. Rata-rata skor ketersediaan sarana dan prasarana produksi yang diperoleh adalah 51,20.

Rata-rata penyuluhan yang diikuti oleh petani muda anggota Kelompok Tani Mekar Sari IV yang menerapkan teknik budidaya padi sawah secara organik dengan metode SRI adalah sebanyak 3 kali dalam satu tahun. Sebesar $96,70 \%$ petani muda di kelompok tani tersebut menunjukkan tingkat partisipasi terhadap penyuluhan yang rendah.

Karakteristik inovasi yang diamati adalah dengan melihat keuntungan relatif, kesesuaian inovasi, kompleksitas inovasi, triabilitas inovasi, dan tingkat observabilitas inovasi tersebut yang diukur dari skor yang diperoleh dari pernyataan petani. Skor rata-rata yang diperoleh untuk karakteristik inovasi adalah 29,17. Angka tersebut menunjukkan bahwa karakteristik inovasi teknik budidaya padi sawah secara organik dengan metode SRI menurut pandangan petani muda anggota Kelompok Tani Mekar Sari IV sudah menunjukkan tingkat yang sedang.

Untuk mengukur peluang pasar, dilihat dari skor penilaian menurut jawaban informan terhadap indikator peluang pasar yang digunakan dalam penelitian ini. Skor rata-rata yang diperoleh adalah 7,60. Angka tersebut menunjukkan bahwa tingkat peluang pasar bagi petani muda anggota Kelompok Tani Mekar Sari IV yang menerapkan teknik budidaya padi sawah secara organik adalah kategori sedang.

\section{Tingkat Motivasi Petani Muda}

Motivasi petani muda dalam menerapkan teknik budidaya padi sawah secara organik dengan metode SRI di Kelompok Tani Mekar Sari IV menunjukkan kategori tinggi, baik untuk motivasi intrinsik maupun motivasi ekstrinsik. Tingkat motivasi petani muda tersebut dalam menerapkan teknik budidaya padi sawah organik dengan metode SRI disajikan dalam Tabel 3.

Tabel 3. Tingkat Motivasi Petani Muda

\begin{tabular}{lc}
\hline \multicolumn{1}{c}{ Motivasi } & Rataan Skor \\
\hline Intrinsik & \\
Memenuhi kebutuhan sehari-hari & 2,93 \\
Menjalin pergaulan & 3,67 \\
Merasa dihargai & 3,07 \\
Semangat dalam bekerja & 3,57 \\
Perasaan menyenangkan & 3,67 \\
Atas dasar kemauan sendiri & 3,13 \\
Rataan Skor Motivasi Intrinsik & $\mathbf{3 , 3 4}$ \\
\hline Ekstrin sik & \\
Mengutamakan mutu produk & 3,40 \\
Pekerjaan yang lebih mudah & 3,07 \\
Harga produk & 3,40 \\
Tidak merugikan & 3,80 \\
Modal yang lebih murah & 2,60 \\
Anjuran penyuluh & 2,53 \\
Melihat keberhasilan petani lain & 3,17 \\
Rataan Skor Motivasi Ekstrinsik & $\mathbf{3 , 1 4}$ \\
\hline Total Rataan Skor & $\mathbf{3 , 2 4}$ \\
\hline
\end{tabular}

Keterangan: Rendah $=1,00-1,99$; Sedang $=2,00$ 2,99; Tinggi $=3,00-4,00$

Berdasarkan data dalam Tabel 3 diatas, terlihat bahwa rataan skor motivasi intrinsik petani muda lebih besar daripada rataan skor motivasi ekstrinsiknya. Hal ini menunjukkan bahwa motivasi intrinsik petani muda lebih berperan dibandingkan dengan motivasi ekstrinsiknya dalam hal penerapan teknik budidaya padi sawah secara organik dengan metode SRI. Beberapa penelitian lain menyatakan bahwa motivasi intrinsik dapat secara efektif dalam memotivasi pegawai dalam bekerja (Nasri dan Charfeddine; Giancola dalam Bergström dan Martínez, 2016). Motivasi intrinsik juga memiliki peran yang penting dalam menentukan perilaku 
seseorang (Lin dalam Bergström dan Martínez, 2016).

Petani muda tersebut tidak merasa rugi baik secara tenaga, biaya, waktu, serta hal lainnya dalam menerapkan teknik budidaya padi sawah secara organik dengan metode SRI. Hal ini membuat motivasi petani muda anggota Kelompok Tani Mekar Sari IV dalam menerapkan teknik budidaya padi sawah secara organik dengan metode SRI, paling tinggi berasal dari perasaan tidak merugikan yang dirasakan oleh petani muda tersebut berdasarkan nilai rataan skor yang diperoleh.

Motivasi yang berasal dari anjuran dari penyuluh menunjukkan nilai rataan skor yang paling kecil. Hal ini dapat disebabkan karena masih rendahnya tingkat partisipasi petani muda dalam kegiatan penyuluhan tentang usahatani padi sawah secara organik dengan metode SRI.

\section{Hubungan Faktor Internal Petani Muda dengan Motivasi}

Hasil uji koefisien korelasi Tau-b Kendall untuk melihat hubungan di antara faktor internal petani muda dengan motivasi petani muda dalam menerapkan teknik budidaya padi sawah secara organik dengan metode SRI, menunjukkan bahwa faktor pendidikan formal, pengalaman berusahatani, jumlah tanggungan keluarga, dan luas lahan garapan tidak berhubungan nyata atau berhubungan namun cenderung lemah terhadap motivasi petani. Faktor umur petani, pendidikan non formal dan akses informasi, menunjukkan bahwa terdapat hubungan nyata yang diuji pada taraf kepercayaan $95 \%$ terhadap motivasi petani. Hasil analisis data mengenai hubungan antara faktor internal petani muda dengan motivasinya disajikan dalam Tabel 4.

Tabel 4. Hubungan Faktor Internal Petani Muda dengan Motivasi Petani Muda

\begin{tabular}{lcc}
\hline \multicolumn{1}{c}{ Faktor Internal } & \multicolumn{2}{c}{ Motivasi } \\
\cline { 2 - 3 } & Koefisien Korelasi & $\mathbf{P}_{\text {value }}$ \\
\hline Umur Petani* & $-0,269$ & 0,047 \\
\hline Pendidikan Formal & 0,184 & 0,210 \\
\hline Pendidikan Non Formal* & 0,339 & 0,029 \\
\hline Pengalaman Berusahatani & $-0,098$ & 0,477 \\
\hline Jumlah Tanggungan Keluarga & 0,113 & 0,434 \\
\hline Luas Lahan Garapan & 0,177 & 0,192 \\
\hline Akses Informasi* & 0,329 & 0,019 \\
\hline
\end{tabular}

Keterangan: * Berhubungan nyata pada $\mathrm{p}<0,05$

\section{- Hubungan Umur Petani dengan Motivasi}

Umur petani berhubungan nyata dengan motivasi petani muda anggota Kelompok Tani Mekar Sari IV dalam menerapkan teknik budidaya padi sawah secara organik dengan metode SRI. Koefisien korelasi yang dihasilkan menunjukkan angka yang negatif. Hal ini berarti bahwa semakin tinggi umur petani, maka motivasi petani dalam menerapkan teknik budidaya padi sawah tersebut cenderung akan semakin berkurang. Hal ini sesuai dengan pernyataan Soekartawi (2005) yang menyatakan, bahwa semakin muda umur petani biasanya mempunyai semangat keingintahuan akan sesuatu yang belum mereka ketahui, sehingga petani berumur muda tersebut akan berusaha lebih cepat untuk menerapkan suatu inovasi, dalam hal ini kaitannya adalah penerapan teknik budidaya padi sawah secara organik dengan metode SRI.

\section{- Hubungan Pendidikan Formal dengan Motivasi}

Pendidikan formal tidak berhubungan nyata dengan motivasi petani muda anggota Kelompok Tani Mekar Sari IV dalam menerapkan teknik budidaya padi sawah secara organik dengan metode SRI. Hal ini dapat disebabkan karena rendahnya tingkat pendidikan formal petani muda tersebut, yaitu sebanyak 73,3\% informan hanya menempuh pendidikan formal tidak lebih dari 10 tahun.

\section{- Hubungan Pendidikan Non Formal dengan Motivasi}

Pendidikan non formal berhubungan nyata dengan motivasi petani muda anggota Kelompok Tani Mekar Sari IV dalam menerapkan teknik budidaya padi sawah secara organik dengan metode SRI. Hal ini menunjukkan bahwa semakin tinggi tingkat pendidikan non formal seorang petani muda anggota Kelompok Tani Mekar Sari IV, maka akan semakin tinggi juga motivasinya untuk menerapkan teknik budidaya padi sawah tersebut.

\section{- Hubungan Pengalaman Berusahatani dengan Motivasi}

Pengalaman berusahatani petani muda anggota Kelompok Tani Mekar Sari IV tidak berhubungan nyata dengan motivasinya dalam menerapkan teknik budidaya padi secara organik dengan metode SRI. Lama atau tidaknya pengalaman berusahatani seorang 
petani muda tidak berhubungan atau berhubungan namun lemah terhadap motivasinya untuk menerapkan teknik budidaya padi sawah tersebut.

\section{- Hubungan Jumlah Tanggungan Keluarga dengan Motivasi}

Faktor jumlah tanggungan keluarga tidak berhubungan nyata atau memiliki hubungan namun lemah terhadap motivasi petani muda anggota Kelompok Tani Mekar Sari IV dalam menerapkan teknik budidaya padi sawah secara organik dengan metode SRI. Jumlah tanggungan keluarga yang dimiliki oleh petani muda tersebut cenderung tidak berhubungan dengan motivasinya untuk menerapkan teknik budidaya padi sawah secara organik dengan metode SRI.

\section{- Hubungan Luas Lahan Garapan dengan Motivasi}

Luas lahan garapan tidak berhubungan nyata dengan motivasi petani muda anggota Kelompok Tani Mekar Sari IV dalam menerapkan teknik budidaya padi sawah secara organik dengan metode SRI. Dengan demikian, luas lahan garapan yang dimiliki oleh petani muda tersebut tidak berhubungan atau berhubungan namun lemah terhadap motivasinya untuk menerapkan teknik budidaya padi sawah secara organik dengan metode SRI. Hal ini dapat diakibatkan karena luas lahan yang dimiliki oleh sebanyak $90 \%$ petani muda anggota Kelompok Tani Mekar Sari IV tergolong kategori sempit.

\section{- Hubungan Akses Informasi dengan Motivasi}

Akses informasi berhubungan nyata dengan motivasi petani muda anggota Kelompok Tani Mekar Sari IV dalam menerapkan teknik budidaya padi sawah secara organik dengan metode SRI. Semakin banyak seorang petani muda mengakses informasi mengenai teknik budidaya padi sawah tersebut, maka akan semakin tinggi juga tingkat motivasi untuk menerapkannya. Melalui tingkat akses informasi yang tinggi, maka petani muda tersebut akan mendapatkan pengetahuan dan wawasan seputar teknik budidaya padi sawah secara organik dengan metode SRI.

\section{Hubungan Faktor Eksternal Petani Muda dengan Motivasi}

Hasil uji koefisien korelasi Tau-b Kendall untuk melihat hubungan di antara faktor eksternal petani muda dengan motivasi petani muda dalam menerapkan teknik budidaya padi sawah secara organik dengan metode SRI menunjukkan bahwa faktor ketersediaan modal dana, intensitas penyuluhan dan peluang pasar tidak berhubungan nyata atau berhubungan namun cenderung lemah terhadap motivasi petani. Faktor ketersediaan sarana dan prasarana produksi, dan karakteristik inovasi, menunjukkan bahwa terdapat hubungan nyata yang diuji pada taraf kepercayaan $95 \%$ terhadap motivasi petani. Hasil analisis data mengenai hubungan faktor internal petani muda dengan motivasinya disajikan dalam Tabel 5.

Tabel 5. Hubungan Faktor Eksternal Petani Muda dengan Motivasi Petani Muda

\begin{tabular}{lcc}
\hline \multicolumn{1}{c}{ Faktor Eksternal } & \multicolumn{2}{c}{ Motivasi } \\
\cline { 2 - 3 } & Koefisien Korelasi & $\mathbf{P}_{\text {value }}$ \\
\hline Ketersediaan Modal Dana & 0,037 & 0,786 \\
\hline Ketersediaan Sarana Prasarana* & 0,317 & 0,020 \\
\hline Intensitas Penyuluhan & 0,118 & 0,420 \\
\hline Karakteristik Inovasi* & 0,354 & 0,011 \\
\hline Peluang Pasar & 0,268 & 0,058 \\
\hline
\end{tabular}

Keterangan: * Berhubungan nyata pada $\mathrm{p}<0,05$

\section{- Hubungan Ketersediaan Modal Dana dengan Motivasi}

Ketersediaan modal dana tidak berhubungan nyata dengan motivasi petani muda anggota Kelompok Tani Mekar Sari IV dalam menerapkan teknik budidaya padi sawah secara organik dengan metode SRI. Besar atau kecilnya modal dana, serta sumber dari modal dana tersebut tidak berhubungan atau berhubungan namun lemah terhadap motivasi petani muda dalam menerapkan teknik budidaya padi sawah secara organik dengan metode SRI.

\section{- Hubungan Ketersediaan Sarana dan Prasarana Produksi dengan Motivasi}

Ketersediaan sarana dan prasarana produksi berhubungan nyata dengan motivasi petani muda anggota Kelompok Tani Mekar Sari IV dalam menerapkan teknik budidaya padi sawah secara organik dengan metode SRI. Semakin tinggi ketersediaan jenis dan jumlah dari peralatan pertanian, pupuk kompos dan MOL, pestisida nabati, dan bibit unggul, serta baiknya akses jalan yang mendukung kegiatan usahatani, maka motivasinya petani muda dalam menerapkan teknik budidaya padi sawah tersebut akan semakin tinggi juga. Hal ini sesuai dengan pernyataan BAPEDA Kabupaten Balangan (2015), yang menyatakan 
bahwa dengan lancarnya ketersediaan sarana dan prasarana produksi, akan dapat meningkatkan produktivitas kerja petani.

\section{- Hubungan Intensitas Penyuluhan dengan Motivasi}

Intensitas penyuluhan tidak berhubungan nyata dengan motivasi petani muda anggota Kelompok Tani Mekar Sari IV dalam menerapkan teknik budidaya padi sawah secara organik dengan metode SRI. Hal ini dapat diakibatkan karena rendahnya kegiatan penyuluhan yang diikuti oleh petani muda. Sejumlah $96,70 \%$ petani muda anggota Kelompok Tani Mekar Sari IV hanya mengikuti di bawah 9 kali kegiatan penyuluhan dari total 24 kali kegiatan penyuluhan yang diadakan per tahunnya.

\section{- Hubungan Karakteristik Inovasi dengan Motivasi}

Karakteristik inovasi berhubungan nyata dengan motivasi petani muda anggota Kelompok Tani Mekar Sari IV dalam menerapkan teknik budidaya padi sawah secara organik dengan metode SRI. Semakin positif karakteristik inovasi dari teknik budidaya padi sawah secara organik dengan metode SRI, maka akan semakin tinggi juga motivasi petani muda dalam menerapkannya. Hal ini menunjukkan bahwa teknik budidaya padi sawah tersebut adalah inovasi yang dapat dengan mudah diterima oleh petani muda anggota Kelompok Tani Mekar Sari IV.

\section{- Hubungan Peluang Pasar dengan \\ Motivasi}

Peluang pasar tidak berhubungan nyata dengan motivasi petani muda anggota Kelompok Tani Mekar Sari IV dalam menerapkan teknik budidaya padi sawah secara organik dengan metode SRI. Faktor peluang pasar yang dirasakan oleh petani muda tersebut tidak berhubungan atau berhubungan namun lemah terhadap motivasinya dalam menerapkan teknik budidaya padi sawah secara organik dengan metode SRI. Rendahnya pengetahuan terhadap informasi harga yang selama ini hanya diketahui oleh pengurus kelompok tani, dapat menjadi salah satu alasan hal ini terjadi.

\section{KESIMPULAN DAN SARAN}

Kesimpulan. Berdasarkan pemaparan hasil dan pembahasan pada bagian sebelumnya, maka dapat ditarik kesimpulan berupa:
1. Tingkat motivasi petani muda anggota Kelompok Tani Mekar Sari IV dalam menerapkan teknik budidaya padi sawah secara organik dengan metode SRI termasuk ke dalam kategori tinggi, dilihat dari rataan skor yang diperoleh.

2. Faktor internal petani muda yang berhubungan nyata dengan dengan tingkat motivasinya dalam menerapkan teknik budidaya padi sawah secara organik dengan metode SRI adalah umur petani, pendidikan formal dan akses informasi, sedangkan faktor eksternalnya adalah ketersediaan sarana dan prasarana produksi serta karakteristik inovasi dari teknik budidaya padi sawah tersebut.

Saran. Berdasarkan kesimpulan pada bagian sebelumnya, maka disarankan beberapa hal sebagai berikut:

1. Tingkat motivasi petani muda anggota Kelompok Tani Mekar Sari IV dalam menerapkan teknik budidaya padi sawah secara organik dengan metode SRI yang sudah tergolong kategori tinggi harus dijaga agar tidak mengalami penurunan.

2. Upaya menjaga tingkat motivasi petani muda melalui faktor internal dan eksternal dapat dilakukan dengan cara memberikan informasi dan pengetahuan yang sesuai melalui kegiatan sosialisasi atau pelatihan yang rutin, serta memperbaiki penyediaan sarana dan prasarana produksi pertanian yang layak bagi petani muda melalui pengajuan program pertanian organik kepada pemerintah.

\section{UCAPAN TERIMAKASIH}

Penulis mengucapkan terima kasih kepada Kepala Desa Ciapus beserta jajarannya, Kepala UPT PPP Kecamatan Banjaran beserta jajarannya, serta kepada informan petani muda di Kelompok Tani Mekar Sari IV yang telah membantu dalam mendapatkan data yang diperlukan untuk penelitian ini.

\section{DAFTAR PUSTAKA}

Abdul Makarim dan Ikhwani. 2012. System of Rice Intensification (SRI) dan Peluang Peningkatan Produksi Padi Nasional. Bogor: Puslitbang Tanaman Pangan. BAPEDA Kabupaten Balangan. 2015. Penelusuran Dampak Pemanfaatan Lahan dan Air Pasca Pembangunan 
Sarana dan Prasarana Pertanian Kabupaten Balangan. Dikutip dari: http://bappeda.balangankab.go.id/web/p df_berita/Penelusuran_dampak.pdf (diakses 29 Januari 2017, 14:23 WIB)

Bergström, Emma dan Martínez, Melanie G.

2016. The Influence of Intrinsic and

Extrinsic Motivation on Employee

Engagement: A Qualitative Study of the Perceptions of Managers in Public and Private Sector Organizations. Swedia: Degree Project, Umeå School of Business and Economics.

IFOAM-Organics International. 2015. Into the Future: Consolidated Annual Report of IFOAM-Organics International. Jerman: IFOAM-Organics International.

Karwan A. Salikin. 2003. Sistem Pertanian Berkelanjutan. Yogyakarta: Kanisius.

Marihot Tua Efendi Hariandja. 2002. Manajemen Sumber Daya Manusia: Pengadaan Pengembangan, Pengkompensasian dan Peningkatan Produktivitas Pegawai. Bandung:Grasindo.

Sitanala Arsyad. 2008. Penyelamatan Tanah, Air dan Lingkungan. Jakarta: Yayasan Obor Indonesia.

Soekartawi. 2005. Agribisnis Teori dan Aplikasinya. Jakarta: Raja Grafido Persada.

Sumarno. 2007. Teknologi Revolusi Hijau Lestari untuk Ketahanan Pangan. IPTEK Tanaman Pangan 2(2):131-153. 
Vol. 3, No. 1, Juni 2018: 359-426 AGRICORE-Jurnal Agribisnis dan Sosial Ekonomi Pertanian 